Volume 2, Nomor 1, February 2020, p. $23-28$

ISSN 2655-9951 (print), ISSN 2656-0062 (online)

\title{
Ekstrak buah Mulberry (Morus alba L.) sebagai agen pemutih kulit
}

\author{
Annisa Nur Oktavia Bajuri \\ Fakultas Kedokteran Universitas Lampung \\ Email: annisabajuri3@gmail.com
}

\begin{tabular}{|c|c|}
\hline ARTICLE INFO & A B S T R A C T \\
\hline $\begin{array}{l}\text { Kata Kunci: } \\
\text { Agent } \\
\text { Extract } \\
\text { Melanin } \\
\text { Mulberry } \\
\text { Tyrosinase } \\
\text { Whitening }\end{array}$ & $\begin{array}{l}\text { High oxidants in the body and exposure from the outside can have an } \\
\text { impact on the skin. The skin can become darker and duller. This causes } \\
\text { the use of bleaching agents to be increasingly used. Many whitening } \\
\text { agents that are made from chemical raw materials are toxic so that } \\
\text { breakthroughs in raw materials that are natural and safer are offered. } \\
\text { The natural raw material that can act as a whitening agent is mulberry } \\
\text { fruit. Mulberry extract is rich in phenol, arbutin, tannin, which works } \\
\text { as an antioxidant and tyrosinase inhibitor in the formation of pigments } \\
\text { in the skin. }\end{array}$ \\
\hline
\end{tabular}

*) corresponding author

Fakultas Kedokteran Universitas Lampung1 Jl.Prof. Dr. Ir. Sumantri Brojonegoro No. 1, Gedong Meneng, Kec. Rajabasa, Kota Bandarlampung, Lampung Telp.081272552661

\section{PENDAHULUAN}

Oksigen aktif selalu dihasilkan selama proses respirasi untuk mendapatkan energi yang diperlukan untuk menjaga kesehatan tubuh. Oksigen aktif sangat berbahaya bagi sel-sel kulit, yang menyebabkan pigmentasi, kerutan, dan penurunan elastisitas pada kulit. Sebagai hasilnya, oksigen aktif menekan metabolisme kulit, menghasilkan peningkatan pembentukan pigmen melanin yang merupakan mekanisme pertahanan untuk melindungi kulit. Meskipun melanin yang diproduksi di kulit melindungi kulit dari sinar UV, terlalu banyak melanin meninggalkan noda coklat gelap. Selain itu paparan lain seperti obat dan bahan kimia dapat mempengaruhi. Hal ini menyebabkan 
kulit tampak lebih gelap dan kusam, sehingga mulai banyak penggunaan agen pemutih untuk mengatasi keluhan yang muncul (Gug, K, 2012).

Depigmentasi dan produk pencerah kulit, yang telah digunakan selama berabad-abad di negaranegara Asia di mana putih kulit adalah kriteria estetika utama. Efikasi kosmetik yang menghasilkan efek pencerah kulit diharapkan bertindak dalam tiga arah utama yaitu mencapai warna kulit yang berpigmen tidak merata dan cocok (perbedaan antara bagian kulit yang tertutup dan yang tidak tertutup), pengaruh pada gangguan pigmentasi termasuk bintik-bintik, usia atau bintik-bintik matahari, melasma, bintik-bintik jerawat dari bekas jerawat dll dan pengurangan pigmentasi kulit alami untuk memberikan penampilan warna kulit yang lebih terang (terutama di negara-negara Asia). Untuk mencapai salah satu dari ketiga target ini, semua agen pemutih bertujuan untuk mempengaruhi melanogenesis yaitu mekanisme yang berbeda akan terlibat baik secara individu atau dalam kombinasi (efek sinergis). Depigmentasi dapat dicapai dengan interaksi spesifik aktif yaitu sebelum sintesis melanin, selama sintesis melanin, dan setelah sintesis melanin (S. John, et al., 2005).

Banyak produk yang menawarkan pemutih kulit, alih-alih produk dengan pemutih instan, terdapat pula produk kecantikan yang menawarkan bahan baku alam yang digunakan sebagai pemutih. Salah satunya adalah ekstrak mulberi. Buah mulberi atau Morus alba L. merupakan spesies dari family tanaman Moraceae, dimana tanaman ini berbentuk semak. Bunga dari mulberi tidak berbau, terdapat buah berbentuk drupelet. Pohon mulberi hidup selama 200 hingga 300 tahun (Kochyńska, M., \& Oleszak, G, 2011).

Pengembangan kemungkinan antioksidan alami dan kosmetik fungsional dengan mengukur efek antioksidan dan pemutihan

diharapkan dari daun, cabang, kulit akar, dan buah-buahan mulberry (Gug, K, 2012).. Pada jurnal ini dibahas mekanisme ekstrak mulberi yang dapat berperan sebagai agen pemutih (Łochyńska, M., \& Oleszak, G, 2011).

\section{PROSES MELANOGENESIS}

Di kulit, melanosit terletak pada lapisan basal yang memisahkan dermis dan epidermis. Satu melanosit dikelilingi oleh sekitar 36 keratinosit. Bersama-sama, mereka membentuk yang disebut unit melanin epidermal. Melanin diproduksi dan disimpan di dalam melanosit di kompartemen melanosomal diangkut melalui dendrit ke keratinosit yang dilapis. Pigmen melanin adalah polimer yang diproduksi di dalam melanosom dan disintesis dari asam amino L-tirosin yang dikonversi oleh enzim tyrosinase menjadi dopaquinone (Smit, N, et al., 2009). Reaksi ini berlanjut secara spontan melalui dopachrome ke prekursor indolik monomer (5,6-dihydroxyindole dan 5,6-dihydroxyindole 2-carboxylic acid) dari eumelanin pigmen hitam-coklat. Namun, beberapa enzim lain, seperti protein terkait tirosinase (TRP-1 dan dopachrome tautomerase (TRP-2) juga dapat memainkan peran penting dalam melanogenesis in vivo (Parvez, S, et al., 2006).

Setelah bereaksi dengan sistein, dopaquinon membentuk 2- atau 5-S-cysteinyldopa yang menghasilkan prekursor benzothiazine dari polimer pheomelanin merah / kuning. Secara umum, jenis campuran polimer pheo-

dan eumelanin diproduksi dan disimpan ke dalam protein matriks melanosomal (Smit, N, et al., 2009). Mempertimbangkan banyak variasi warna yang dapat dilihat pada kulit dan rambut, orang dapat berharap bahwa komposisi melanin campuran diatur dalam berbagai cara. Namun, perubahan produksi yang berubah dari melanin kulit dapat menyebabkan masalah yang cukup besar dari sifat 
estetika, terutama dalam kondisi hiperpigmenter, seperti melasma, hiperpigmentasi pascainflamasi, bintik-bintik atau lentigin. Tetapi juga kondisi depigmenting, seperti vitiligo, memiliki dampak tinggi pada kualitas hidup pasien (Parvez, S, et al., 2006).

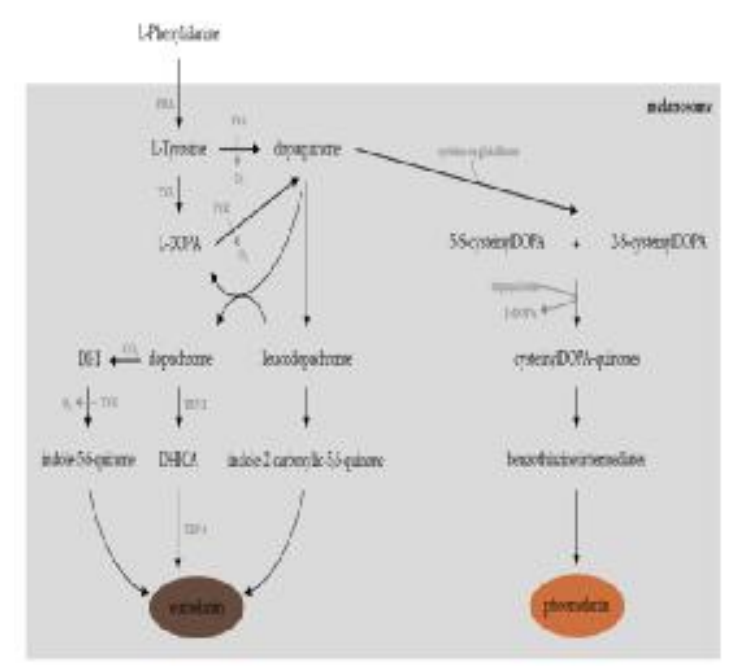

Gambar 1. Proses Melanogenesis ${ }^{5}$

Tirosinase juga dapat secara tidak langsung diaktifkan oleh tyrosine hydroxylase isoenzyme 1 (TH1) karena telah terbukti hadir dalam melanosom dan mengkatalisis sintesis L-dopa. Pada gilirannya, L-dopa dapat bertindak sebagai kofaktor untuk tirosinase. Kondisi redoks dalam melanosom sangat penting untuk keseimbangan antara produksi eumelanin dan pheomelanins (Gillbro, J. M., \& Olsson, M. J. 2011). Pembentukan eu atau pheomelanin ditentukan secara langsung oleh tereduksi glutathione (GSH) (GSH tinggi untuk eumelanin dan rendah untuk pheomelanin). Oleh karena itu, ekspresi dan aktivitas fungsional enzim antioksidan seperti katalase, glutation peroksidase, glutation reduktase dan thioredoksin reduktase kemungkinan memodifikasi jalur melanogenic (Devi, B, et al., 2014).

\section{METODE}

Suatu tinjauan literatur (literatur rewiew) terhadap teori-teori yang relevan. Sumber tinjauan meliputi studi pencarian sistematis database (proquest, ebsco, elsheiver, google cendikia) yang berjumlah 12 jurnal.

\section{HASIL DAN PEMBAHASAN}

\section{Ekstrak Mulberi sebagai agen pemutih}

Dari tahapan melanogenesis, secara kimiawi atau enzim katalis, dapat dihambat. Beberapa pendekatan dilakukan untuk menemukan zat kimia yang mampu menginhibisi aktivitas katalis dari tyrosinase dan menggagalkan sintesis serta pelepasan melanin. Ekstrak mulberry telah ditemukan memiliki sifat flavonoid dan anti-oksidan (Akhtar, N, et al., 2012). Mirip dengan agen pemutih lain yang disebutkan di atas, ekstrak mulberry menghambat aktivitas tirosinase secara kompetitif, dan tidak ada penekanan sintesis tirosinase dan ekspresi gen. Aktivitas penghambat tirosinase dari ekstrak mulberry sebanding dengan hidrokuinon dan asam kojic (Ong, M. W. S., \& Maibach, H. I. (2017). 
Mulberry (Morus alba) memiliki senyawa fenolik tinggi yang memiliki kadar total tinggi Antosianin. Antosianin dianggap agen antioksidan yang sangat baik. Padah ekstrak mulberi juga terkandung anthocyanin, asam galat, flavonoid dan tanin dalam mencegah kerusakan sel menjadikan mereka kandidat terkuat untuk aplikasi kosmetik. Selain itu, kandungan seperti asam benzoat dan asam hidroksinamik juga mengandung anti-oksidan, juga terdapat aktivitas penghambat tirosinase dan peran pembilasan radikal bebasnya, penting dalam pemutih kulit kosmetik (Parvez, S, et al., 2006).

Stres oksidatif berkontribusi terhadap penuaan kulit dan dapat mempengaruhi kesehatan kulit. Antioksidan yang aktif dalam sel-sel kulit dapat mendukung kesehatan kulit. Morus alba telah dilaporkan menunjukkan penghambatan tirosinase dan efek penghambatan pada aktivitas tirosinase dan pembentukan melanin dalam sel melanoma B-16. Obat herbal ini telah digunakan sebagai aditif kosmetik sebagai antipenuaan dan pemutih kulit. Senyawa yang dikaitkan dengan mencerahkan kulit adalah arbutin, suatu bentuk alami hidrokuinon yang menghambat pelepasan melanin dengan menekan enzim tyrosinase (Gug, K, 2012).

Buah mulberi juga kaya akan vitamin C. vitamin $\mathrm{C}$ dipercaya bekerja sebagai anti-oksidan. Asam askorbat atau vitamin $\mathrm{C}$ mudah terdegradasi oleh oksidasi, terutama dalam media berair. Untuk alasan ini, lebih disukai untuk menggunakan turunan yang lebih stabil seperti ascorbyl palmitate dan magnesium-L-ascorbyl-2-phosphate (MAP). Vitamin $\mathrm{C}$ dan turunannya bertindak sebagai reduksi dan memblokir rantai oksidasi yang mengubah tirosin menjadi melanin pada titik yang berbeda. Lebih lanjut, interaksi asam askorbat dengan tembaga, kofaktor penting dalam aktivitas tirosinase, menjelaskan efek inhibitor tirosinase yang diamati secara in vitro. Meskipun kurang efektif daripada hidrokuinon, asam askorbat tidak memiliki efek berbahaya dari yang terakhir (Couteau, C., \& Coiffard, L, 2016). Tindakan utama di balik efek pengurang pigmen dari flavonoid mungkin adalah ikatan penggerusan ROS dan kemampuan untuk mengkelat logam di lokasi aktif metalloenzymes (Gillbro, J. M., \& Olsson, M. J. 2011). Kandungan dari ekstrak mulberi membuat buah ini dapat dipertimbangkan sebagai bahan baku sebagai agen pemutih yang aman (Lee, S. Y, et al., 2015).

Daun dari tanaman murbei putih (Morus alba) mengandung polifenol yang setelah dilakukan pengujian secara in vitro, menunjukan bahwa tanaman ini memiliki sifat depigmentasi. Pengujian telah dilakukan di China dengan menggunakan arbutin sebagai standar. Hasil penelitian menunjukan bahwa ekstrak murbei putih dengan dosis $100 \mu \mathrm{g} / \mathrm{ml}$ dapat menginhibisi tirosinase sebesar 70\% sementara arbutin membutuhkan dosis $138 \mu \mathrm{g} / \mathrm{ml}$ (Yang, et. al., 2012).

Tak hanya daunnya, fraksi air dan etanol dari akar murbei putih menunjukkan efikasi depigmentasi yang lebih besar dibandingkan dengan asam kojic sebagai kontrol positif. Inhibisi tirosinase ini dapat disebabkan oleh pembentukan ikatan hidrogen dari gugus hidroksil senyawa fenol yang terkandung dalam ekstrak akar murbei putih dengan situs aktif pada enzim (Hanh, et. al., 2017)

\section{SIMPULAN DAN SARAN}

Hiperpigmentasi disebabkan peningkatan produksi melanin yang disebabkan berbagai macam faktor. Hiperpigmentasi dapat ditekan dengan penggunaan agen pemutih yang bekerja menekan pembentukan melanin. Agen pemutih dapat berasal dari tanaman buah yang kaya akan fenol, arbutin dan vitamin. 


\section{DAFTAR PUSTAKA}

Akhtar, N., Hisham, J., Khan, H. M. S., \& Khan, B. A. (2012). Whitening and Antierythemic effect of a cream containing Morus alba extract. Hygeia.J.D.Med.V, 4(1), 97-103.

Couteau, C., \& Coiffard, L. (2016). Overview of Skin Whitening Agents : Drugs and Cosmetic Products. Cosmetics, 3(27), 1-16.

Devi, B., Sharma, N., Kumar, D., \& Jeet, K. (2014). Morus alba Linn : A phytopharmacological review. International Journal of Pharmacy and Pharmaceutical Sciences, 5(2), 1-5.

Faizatuna, e. A., Djajadisasrab, J., \& Mardliyati, E. (2017). The Study of Antioxidant and Antityrosinase Activity of Extract from Mulberry Root (Morus alba L .). J. Pharm. Sci. \& Res, 9(11), 2004-2008.

Gillbro, J. M., \& Olsson, M. J. (2011). The melanogenesis and mechanisms of skin-lightening agents - existing and new approaches. International Journal of Cosmetic Science, (33), 210 221.

Gug, K. (2012). Physiological and Whitening Effects of Morus alba Extracts. J. of the Chosun Natural Science, 5(1), 46-52.

Hanh, N. T. M., Phung, N. K. P., dan Phuong, Q. N. D. 2017. Studying on tyrosinase inhibition activity of some Vietnamese folk plants aims to use in skin-whitening cosmetics. American Journal of Plant Sciences. 8 : 1319 - 1328.

Lee, S. Y., Baek, N., \& Nam, T. (2015). Natural, semisynthetic and synthetic tyrosinase inhibitors. Journal of Enzyme Inhibition and Medicinal Chemistry, 00(00), 1-13.

Łochyńska, M., \& Oleszak, G. (2011). Multi-use of the white mulberry ( Morus alba L .). Ecological Questions 15/2011:, 0(0), 1-6.

Ong, M. W. S., \& Maibach, H. I. (2017). Skin Whitening Agents. In Handbook of Cosmetic Science and Technology (pp. 423-438).

Parvez, S., Kang, M., Chung, H., Cho, C., Hong, M., Shin, M., \& Bae, H. (2006). Survey and Mechanism of Skin Depigmenting and Lightening Agents. Phytother. Res, 29, 921-934.

S. John, P., Lorenz, R.-D., Petersen, M., Heldermann, \& Borchert, S. (2005). Skin-Lightening Agent with Different Pathways of Action on Melanogenesis Keywords: SOFW, 131(7), 40-49.

Smit, N., Vicanova, J., \& Pavel, S. (2009). The Hunt for Natural Skin Whitening Agents. Int. J. Mol. Sci., (10), 5326-5349.

Yang, Z., Wang, Y., Wang, Y.; Zhang, Y. 2012. Bioassay-guided screening and isolation of $\alpha$ glucosidase and tyrosinase inhibitors from leaves of Morus alba. Food Chemistry. 131 : 617 $-622$. 
Wellness and Healthy Magazine, 2(1), February 2020, - 28

Annisa Nur Oktavia Bajuri 